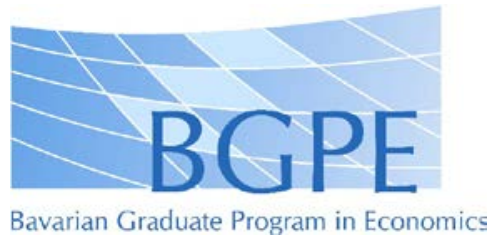

BGPE Discussion Paper

No. 163

\title{
Central Bank Transparency and Inflation (Volatility) - New Evidence
}

\author{
Christoph S. Weber
}

March 2016

ISSN 1863-5733

Editor: Prof. Regina T. Riphahn, Ph.D.

Friedrich-Alexander-University Erlangen-Nuremberg

(c) Christoph S. Weber 


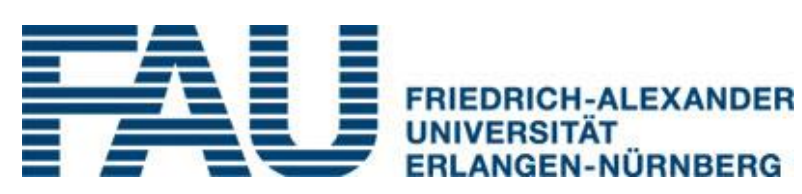

\title{
Central Bank Transparency and Inflation (Volatility) - New Evidence
}

\author{
Christoph S. Weber
}

March 2016

Address for correspondence:

Christoph Weber

Institute of Economics

University of Erlangen-Nuernberg

Kochstr. 4 (17)

D-91054 Erlangen

Germany

Phone: (+49) 91318522733

Fax: (+49) 91318522060

E-mail: Christoph.Weber@fau.de

Internet: www.economics.phil.fau.de 


\begin{abstract}
:
The last decades have shown a tendency towards higher central bank transparency. It became customary for central bankers to explain their monetary policy decisions in detail and for them to publish inflation forecasts. This leads to the question of how central bank transparency is entangled with price stability and inflation volatility. A plethora of studies analysed the relationship from a theoretical point of view and came to contradictory results. Whilst some studies argued that transparency leads to lower inflation, others concluded that openness of central banks results in higher prices. Conversely, there is only a small amount of studies looking at this issue empirically. Most studies found a diminishing effect of transparency on inflation. However, these studies hardly controlled for other causes of inflation. This paper tries to close this gap by employing a panel data set on central bank transparency. We find that transparency significantly reduces inflation rates even if we control for other determinants of inflation. This result still holds under various robustness checks. The same is true for inflation volatility: central bank transparency seems to diminish inflation uncertainty. This confirms the economic importance of central bank transparency.
\end{abstract}

JEL: E31, E42, E58

Keywords: Central Bank Transparency, Inflation, Inflation Volatility, Determinants of Inflation, Central Bank Independence 


\section{Introduction}

The last decades have shown some general trends in central banking. After the breakdown of the Bretton-Woods system, monetary policy was more flexible as it was not necessary to target exchange rates anymore. Most industrialised countries were plagued by relatively high inflation rates in the seventies. The rational expectations revolution shifted the focus from output stabilisation to maintaining price stability. On the institutional level, various central banks were granted more independence. This mainly applies to instrument independence meaning the chance for central banks to choose measures independently without the approval of the government. On the other hand, most central banks do not have goal independence as their objectives are laid down in laws or constitutions. The abolishment of fixed exchange rate systems plus the increase in independence also changed the importance of monetary policy strategies. Some time ago, monetary targeting was the predominant strategy whereas nowadays a multitude of countries conduct inflation targeting. The other main development in central bank along with the changes mentioned above is that central bank transparency has been increased by most central banks in the world. There are mainly two reasons for this increase in openness. Firstly, transparency can be seen as the flipside of central bank independence. Most central bankers are only indirectly democratically legitimised. Thus, there is no direct way in which the public can control or influence central bank measures if monetary policy makers enjoy instrument independence. Then there is a strong need for explaining and justifying the policy decisions. The other reason why many central banks became more transparent in recent years was that (a certain degree of) central bank transparency is desirable from an economic point of view. Many studies show that transparency is welfare enhancing and can lead to better economic outcomes. One question of highest interest is how transparency and inflation are related. Price stability is among the main targets of practically every central bank. However, there is no accord in the theoretical literature regarding the effects of transparency on inflation. On the other hand, there have only been a few studies analysing this relationship empirically. Thus, the aim of this paper is to analyse the effect of transparency on inflation and inflation variability with a large panel data set which takes into account inflation driving factors.

The remainder of this paper is structured as follows. Section 2 gives an overview of the theoretical and empirical studies on the relationship between central bank transparency and inflation (volatility). Section 3 describes the data and the estimation procedure. In Section 4, estimation results are presented and discussed. Section 5 concludes.

\section{Literature Review}

The discussion about the role of central bank transparency for inflation started over two decades ago. This section will give an overview of theoretical papers on the relationship and will then show which empirical studies have been conducted so far. 


\subsection{Theoretical Assumptions}

The causal association between transparency by central banks and inflation has been analysed quite a lot. There is a plethora of studies showing that transparency could decrease inflation rates. Walsh (1999) shows that inflation rates can be lower in an inflation targeting system. If individuals increase their inflation expectations if the central bank had not met its target, then it will be expensive for the central bank to create surprise inflation. On the other hand, it is assumed that the public is not aware of supply shocks making these shocks private information for the central bank. Then central bankers could mislead the public by saying that an unexpectedly high inflation rate was the result of a supply shock. If the central bank announces its inflation target, the option of fooling the public is less attractive to the central bank which leads to lower inflation rates overall. Schaling and Nolan (1998) argue that countries with bad a reputation and low de jure independence can gain from being more precise about their targets. According to them, central bank transparency can work as a substitute for formal independence or conservativeness. This comes from the fact that uncertainty about the central bank's preferences leads to higher inflation expectations. Eijffinger et al. (2000) find that central banks with low transparency regarding their preferences are perceived as less conservative which leads to higher inflation via increased inflation expectations by employees. They also come to the conclusion that uncertainty about the central bank's preferences end up in higher inflation variability. These findings are in line with those of Hughes Hallett and Libich (2006) who also argue that goal transparency is favourable for stable prices. Geraats (2005) emphasises that economic transparency is beneficial for inflation stabilisation. If the public is better informed about the central bank's economic forecasts, then it can derive more meaningful conclusions from the actual monetary policy. Westelius (2005) employs a Barro-Gordon type of model to show that in a neoclassical economy imperfect transparency decreases inflation persistence. Initially, the fact that central banks can conduct discretionary monetary policy leads to overall higher equilibrium inflation rates because the public takes into account the possibility and the incentive for the central bank to make use of the Philipps curve trade-off. Transparency is then measured by the standard deviation of the error term of inflation. In this model, transparency leads to lower inflation persistence.

On the other hand, there is a multitude of studies saying that central bank transparency is not always advantageous for maintaining price stability. Among these is the work by Sørsensen (1991) who reaches the conclusion that political uncertainty (e.g. uncertainty about the central bank's preferences towards output and price stabilisation) leads to lower inflation rates. The effect comes from the fact that unions set lower nominal wages if the central bank's response to an increase in nominal wages is unclear. Grüner (2002) follows that argument and reaches the same conclusion that uncertainty is beneficial in terms of lower inflation rates. In Sibert's model (2002) opaqueness of the central bank regarding its preferences towards output and price stabilisation is considered to be positive. The reason for that conclusion is that private agents would just refer to their expectations about the possible central banker's preferences if there is no political transparency. In a signalling game, the central bank would like to pretend that it is conservative in order to reduce the welfare loss induced by the time-inconsistency problem. Thus, the central bank will have to conduct more restrictive monetary policy in order to be viewed as conservative. Mishkin (2004) argues that publishing the central bank's objective function aggravates the time-inconsistency problem if the objective function just makes the public aware of the fact that the central bank cares about output. Cukierman (2002) shows that a central bank that does not publish its economic models and objectives is more likely to have higher credibility. If agents are not fully rational, the publication of the objective function may increase inflation expectations in a situation where the central bank has asymmetric preferences 
towards output and inflation stabilisation. Within a New Keynesian model Westelius (2009) discusses the role of forward guidance. When the central bank acts discretionarily, inflation will be higher the higher transparency is. This is a case for imperfect transparency.

Overall, there is no consensus with respect to the debate whether central bank transparency is positive in terms of stable prices or not. This opens the field for empirical analyses that can tell what the data say about this question.

\subsection{Empirical Evidence}

There is a certain number of studies that has analysed the role of transparency on inflation before. Cecchetti and Krause (2002) analyse average inflation from 1995 to 1999 from 60 countries. They use the approach of Fry et al. (2000) for measuring central bank transparency. Firstly, they find transparency to be negatively correlated with average inflation. Secondly, they conduct a multivariate regression with the explanatory variables independence, accountability, transparency, and credibility. There is still a negative relationship between transparency and average inflation when the additional variables are included. However, the link turns out to be significant only if credibility is not included in the regression. Levin et al. (2004) employ an event-study approach to analyse the effect of inflation targeting. They compare five inflation targeting countries to three non-inflation targeting countries. The evidence shows that inflation expectations are closer to the target level if the inflation target is common knowledge and the central bank is credible. On the other hand, individuals' inflation forecasts merely rely on past and current inflation when the inflation target is unknown or the central bank is unreliable. In a study with eleven countries Siklos (2003) concludes that transparency leads to lower inflation expectations. The data set consists of five countries without and six countries with a formal inflation targeting system in practice. The effect is captured by a simple dummy variable for being an inflation targeting country. Only in the sample 1990 to 1999 does this dummy have a significant negative effect on inflation forecasts. Fatás et al. (2007) cover the question of whether political transparency has any macroeconomic effect. They analyse 42 countries over the period 1960 to 2000. Political transparency is captured by a dummy which tells us whether a central bank has a formal quantitative objective or not. Central bank could either have an inflation target, an exchange rate target, or a money growth target. They find overwhelming evidence that having an explicit goal reduces inflation. The results are robust to several robustness checks. Demertzis and Hughes Hallett (2007), on the other hand, show both theoretically and empirically that transparency has no impact on average inflation but would only lead to lower inflation variability. They use the Eijffinger-Geraats index to compute the correlation between transparency and average inflation for nine countries with data from the 1990's to 2001. Surprisingly, the correlation turns out to be positive but insignificant. Crowe and Meade (2007) also find no significant relationship between transparency and inflation. They used both the Eijffinger-Geraats index and the index of Chortareas et al. (2001) for 37 countries. Chortareas et al. (2001) themselves employed the Fry et al. (2000) data on central bank transparency. This is merely a cross-country comparison of 87 countries and their average inflation rates from 1995 to 1999. They find a significant negative correlation between transparency and inflation (variability). Furthermore, they conducted a multivariate analysis controlling for many other explanatory factors (e.g. political instability or whether a country has a fixed exchange rate). Transparency turns out to have a negative impact on inflation in this regression as well. Cournède and Minegishi (2009) estimate the impact of transparency on inflation expectations for eleven countries from 1999 to 2008. In a panel data estimation with fixed effects they find that an interaction term between transparency and actual inflation has 
significantly negative influence on inflation expectations. The control variables are actual inflation and forecasts for the unemployment rate two years ahead. Finally, Dincer and Eichengreen (2014) employ a huge panel data set to figure out the effect of transparency. However, they only control for openness and financial depth in a fixed effects and a panel GMM model. This justifies another empirical study on the question of the impact of central bank transparency accounting for other determinants of both inflation and inflation volatility.

\section{Data}

When it comes to the question which explanatory variables should be included in the estimation, one should firstly recall the potential causes of inflation. There are four main reasons for inflation: demand-pull inflation, cost-push inflation, money growth, and expectation driven inflation. Let us start with demand driven inflation. From a simple AS-AD model one can infer that an increase in aggregated demand leads to higher prices in the short run if the production capacity is not underutilised and the supply curve is upward sloping due to short-run rigidities of prices and wages. Such an increase in demand could be the result of expansionary fiscal policy or a change in the mood of consumers to spend more (i.e. an increase in the consumption rate). A depreciation of the local currency could also lead to increased demand from foreign consumers. However, aggregated demand cannot easily be estimated. A natural proxy would be GDP which we will use in the first instance. Cost-push inflation is another reason for inflation. Let us use the simple AS-AD model again. Cost-push inflation refers to an upward shift of the short-run aggregated supply curve which leads c. p. to a higher price level. Whether this price increase is permanent depends on to what extent producers can substitute the goods that got more expensive. Cost-push inflation could have several reasons. It might simply be the result of higher costs of production induced by increases of input prices or wages. To be precise, prices should only increase after nominal wage increases if the wage increases were higher than the increase in output the employees produced (e.g. only if unit labour costs increased). A compensation of workers for productivity gains or inflation should not lead to price pressure. If, however, employees or unions indulged themselves a little bit more than that, a wage/pricespiral could be set in motion. Also tax increases (corporate taxes and especially value added taxes) could translate into price rises. This depends on market conditions (mainly supply and demand price elasticity). In practice, the price increase will be larger the more price inelastic the aggregated demand is. Also a depreciation of the local currency could lead to cost-push inflation because then the prices of imported goods expressed in local currency increase. This is also called imported inflation. This problem arises especially when there are no substitutes available for the imported goods and when the imported goods are necessary products (e.g. oil or food). Such a pass-through of exchange rates to import prices is well documented in the literature (e.g. Campa and Goldberg (2005)), whereby the effect is larger for emerging countries (Frankel et al. (2012)). Aggregated supply cannot easily be captured by a specific variable but there are some factors that could pick up parts of the described effects. Tax rates and wages or unit labour costs should be used. Furthermore, crop or food production play a huge role in developing countries especially because food prices account for a larger share of CPI baskets in low income countries. ${ }^{1}$ In general, aggregated supply plays a larger role in developing countries given that the production of primary products is more important in those countries. There a bad harvest due to droughts or floods can lead to a substantial decrease in GDP (Frankel

\footnotetext{
${ }^{1}$ There is a clear negative relation between GDP per capita and the share of food in CPI baskets (Yörükoglu (2010)).
} 
(2011)). The other problem related to food prices is that income elasticity of food demand is much higher in developing countries. Thus, an increase in income can translate into an overall rise in world food prices which affects the inflation rates of all countries and in particular those of low-income countries (Yörükoglu (2010)). At the same time, GDP growth could lead to accelerated urbanisation and industrialisation in developing countries and thus to a decrease of agricultural production which worsens the problem even more (ibid.). These worldwide effects can be partly covered by the inclusion of time fixed effects in a panel data estimation. Imported inflation can be captured by nominal exchange rate changes. ${ }^{2}$

From Milton Friedman we know well that "inflation is always and everywhere a monetary phenomenon in the sense that it is and can be produced only by a more rapid increase in the quantity of money than in output" (Friedman (1970), p. 24). This is just what the quantity theory of money tells us: Inflation rates increase if the money growth increases, the velocity of money increases and/or the national income decreases. There is overwhelming evidence for the (longterm) correlation between money growth and inflation (see, e.g., Rolnick and Weber (1997)). However, this relation very often breaks down for low inflation countries (de Grauwe and Polan (2005)). Still, we include money growth as an explanatory variable.

Apart from that, several other factors could have an impact on inflation. Clearly, real interest rates should be included given that they describe to a large extent how expansionary monetary policy is. Trade openness seems to play a role as well. There are several channels through which openness affects price. ${ }^{3}$ The negative relationship between openness and inflation is well documented in the literature (see, e.g., Gruben and McLeod (2004) or Sachsida et al. (2003)). Thereby, openness is usually measured as the sum of imports and exports as a percentage of GDP. In the same manner, capital account openness seems to reduce average inflation (Gruben and McLeod (2002)). Public debt could have an indirect impact on inflation as central banks of highly indebted countries might feel a need to help financing the government debt no matter how (legally) independent it is. This problem might especially arise when the government has difficulties with tax collection. In such a scenario seignorage becomes a more important source of government income. The empirical study by Cukierman et al. (1992a) documents clearly that unstable countries and countries with a polarised political system rely much more on central bank profits. The positive relation between political instability and inflation was confirmed by Aisen and Veiga (2006). This may also explain why corruption is positively correlated with inflation (Al-Marhubi (2000)). The populist approach in public choice theory argues that democratic systems lead to higher inflation rates through a more excessive use of inflation taxes in order to finance demands by the public (Desai et al. (2003)). Empirically, there is a correlation between democracy and inflation (Gasiorowski (2000)). According to Desai et al. (2003), this effect is contingent upon income equality which gives sense to the positive relation between inequality and inflation (Al-Marhubi (1997)). In fact, there is strong evidence that fiscal deficits do translate into higher inflation rates in the long-run in developing countries (Catao and Terrones (2005)). Moreover, central banks may also accommodate expansionary fiscal policy to prevent a crowding out of private investments. Some authors even go so far as to say that the central bank has no influence on the price level. In their mind, the price level is just "the ratio of nominal debt to the present value of real primary surpluses" (Cochrane (2001), p. 69). This is called the fiscal theory of the price level. Also the labour market could be influential. Bowdler and Nunziata (2007) showed that both employment protection and

\footnotetext{
${ }^{2}$ At the same time, exchange rate changes can have an impact on the real economy. For developing countries, devaluations could be contractionary as studies like those of Bahmani-Oskooee and Miteza (2006) or Chou and Caho (2001) for Asian countries show. However, other studies do not find evidence for contractionary effects of devaluations on developing countries (e.g. Narayan and Narayan (2007)).

${ }^{3}$ Daniels et al. (2005) give a good overview of the theoretical discussion about the relationship between openness and inflation.
} 
unionisation lead to higher inflation rates in OECD countries. We also try to control for these factors in our study.

There is another factor that we should take into account. It is reasonable to assume that central bank transparency is correlated with independence. The reason for that is that central bank autonomy comes hand in hand with a decrease in direct democratic legislation. Thus, monetary policy makers are then urged to be more transparent about their actions. Surely, the public would only accept that it has no say if the autonomy of the central bank leads to better economic outcomes. But why should central bank independence (CBI) be relevant for price stability? There are some theoretical assumptions that shed some light on this question. Firstly, governments might try to exploit the short-term trade-off between inflation and unemployment in order to increase their re-election chances. This is well known as the Nordhaus' (1975) political business cycle model. Rational agents would then increase their inflation expectations. A general problem of monetary policy is that there is an option to use surprise inflation for the benefit of higher short-term welfare. This results from the famous time-inconsistency problem mentioned by Kydland and Prescott (1977). Even though granting a central bank autonomy would not spirit away the issue, it is at least reasonable to assume that independent central banks would exploit the trade-off less frequently. Furthermore, the attitudes of monetary policy towards output and price stabilisation would be less consistent assuming that left- and rightwing governments put a somewhat different focus on those two macroeconomic gaols. If political leaders are mainly interested in satisfying their partisans, this would lead to higher output and inflation variability (Hibbs (1977)). A more autonomous central bank is expected to concentrate more on long-term developments or, in other words, they tend to be more conservative in Rogoff's (1985) sense. Moreover, the central bank might be more involved in financing public debt if it is more dependent on the government. Hayo and Hefeker (2002) criticise that central bank independence is neither a necessary nor a sufficient condition for stable prices. However, the negative effect of central bank independence on average inflation is well documented in the literature (see e.g. Crowe and Meade (2008)). Thus, we should control for that effect.

In order to know which of the potential causes are most important, it is instructive to look at an IMF study from 1996. In this study, the short-, medium-, and long-term causes of inflation for industrialised and developing countries are figured out. Intriguingly, in industrialised countries exchange rate changes are responsible for more than $60 \%$ of short-term inflation followed by oil prices (around $25 \%$ ). In the medium-term the output gap is most important along with money growth, exchange rates, and oil prices. In the long-run, demand-pull inflation is predominant together with money growth. Oil prices and exchange rates play a minor role. For developing countries, a different picture can be seen. Exchange rates are by far the most important factor over all time spans. Apart from imported inflation, money growth is highly relevant. Those two factors can explain at least $80 \%$ of inflation in developing countries (IMF (1996)). But why should we care at all about all those factors? Well, simply because more transparent central banks could be, for instance, more conservative. Then the coefficient for the central bank transparency index would pick up other effects and could not tell us the actual effect of transparency.

In addition, we are interested in the effect of central bank transparency on inflation volatility. There are various measures for inflation volatility: some papers use unconditional volatility measures like the standard deviation of mean inflation in different variants (e.g. Bleaney and Fielding (2002), Aisen and Veiga (2008), or Willard (2012)) while others use measures of conditional volatility based on ARCH models (e.g. Apergis (2004) and Tas and Ertugrul 
(2013)). ${ }^{4}$ We use the standard deviation (SD) of mean inflation and $\operatorname{GARCH}(1,1)$, $\operatorname{EGARCH}(1,1), \operatorname{GJR}(1,1), \operatorname{TGARCH}(1,1), \operatorname{NGARCH}(1,1)$, and $\operatorname{APARCH}(1,1)$ models to compute inflation volatility. We use three different measures for the standard deviation. Firstly, we use the SD of monthly inflation rates (annual inflation rates) per year. Secondly, we compute the SD of month-to-month CPI inflation rates per year. Thirdly, we take the SD of annual inflation over the last 12 months for every month and then compute the mean of those standard deviations per year. When we estimate the GARCH models, we model the inflation rates $p_{i, t}$ as an $\operatorname{AR}(1)$ process. ${ }^{5}$

$$
p_{i, t}=\eta_{i}+\varphi_{1} \pi_{i, t-1}+\epsilon_{i, t}
$$

Here $\pi_{i, t}$ is the inflation rate of country $i$ in month $t$. Then the conditional variance is modelled in six different ways. For the $\operatorname{GARCH}(1,1)$ we use the following equation where $h_{i, t}$ is the conditional variance of country $i$ in month $t$.

$$
h_{i, t}=\omega^{\prime} z_{i, t}+\kappa_{1}\left(\left|\varepsilon_{i, t-1}\right|\right)^{2}+\mu_{1} h_{i, t-1}
$$

The GJR(1,1) model based on Glosten et al. (1993) uses the following model:

$$
h_{t}=\omega^{\prime} z_{t}+\kappa_{1}\left(\left|\varepsilon_{t-1}\right|+\gamma_{1} \varepsilon_{t-1}\right)^{2}+\mu_{1} h_{t-1}
$$

The Threshold ARCH (TGARCH(1,1)) approach by Zakoian (1994) models the conditional variance like this:

$$
\sqrt{h_{t}}=\omega^{\prime} z_{t}+\kappa_{1}\left(\left|\varepsilon_{t-1}\right|+\gamma_{1} \varepsilon_{t-1}\right)+\mu_{1} \sqrt{h_{t-1}}
$$

The Non-linear GARCH (NGARCH(1,1)) proposed by Higgins and Bera (1992) employs the following expression:

$$
{\sqrt{h_{t}}}^{\delta}=\omega^{\prime} z_{t}+\kappa_{1}\left(\left|\varepsilon_{t-1}\right|\right)^{\delta}+\mu_{1}{\sqrt{h_{t-1}}}^{\delta}
$$

The Asymmetric Power ARCH (APARCH(1,1)) following Ding et al. (1993) applies the following term:

$$
{\sqrt{h_{t}}}^{\delta}=\omega^{\prime} z_{t}+\kappa_{1}\left(\left|\varepsilon_{t-1}\right|+\gamma_{1} \varepsilon_{t-1}\right)^{\delta}+\mu_{1}{\sqrt{h_{t-1}}}^{\delta}
$$

Finally, we use an E-GARCH(1,1) model originally proposed by Nelson (1991):

$$
\ln \left(h_{t}\right)=\omega^{\prime} z_{t}+\left(\kappa_{1}\left|\varepsilon_{t-1}\right|+\gamma_{1} \varepsilon_{t-1}\right)+\mu_{1} \ln \left(h_{t-1}\right)
$$

In all cases, $\omega$ is defined as $\bar{\omega}$ minus $\sqrt{2 / \pi} \cdot \sum_{i=1}^{q} \kappa_{i}$ (Lucchetti and Balietti (2011)). Of course, equation (1) and the respective GARCH models are always computed simultaneously. Then we save the estimated conditional standard deviations and compute the average per year. For the estimation of volatility models, monthly data on inflation rates from 1996 to 2011 is employed.

As a matter of course, we have to control for other determinants of inflation volatility in order to isolate the impact of transparency. Previous studies found all kinds of explanatory factors

\footnotetext{
${ }^{4}$ According to Batchelor and Dua (1996), these measures are only indirect measures of inflation uncertainty that are not highly correlated with direct measures for inflation uncertainty. Thus, we have to be cautious when interpreting inflation volatility as inflation uncertainty.

${ }^{5}$ In the cases where no convergence for the GARCH models was achieved, we eliminated the AR(1) from the estimation of the inflation rate. This should not be problematic as we include country fixed effects in the estimation of the determinants of inflation volatility.
} 
including lagged inflation volatility, mean inflation, the standard deviation of different macroeconomic variables like GDP or money growth, economic development, openness, and political variables.

The data is mainly taken from the World Bank Development Indicators. We also use data from the International Financial Statistics (for monthly data), Worldwide Governance Indicators (WGI), Polity IV, OECD, and Freedom House. Finally, we use the data of Dincer and Eichengreen (2014) on central bank transparency and independence. There are several ways of measuring those two variables. The most commonly used index for central bank transparency is the Eijffinger-Geraats-Index (Eijffinger and Geraats (2006)) with its dimensions political transparency, economic transparency, policy transparency, operational transparency, and procedural transparency. In the same manner, there are various measures for central bank independence. Here we use the unweighted index of de jure central bank autonomy proposed by Cukierman et al. (1992b). The information about which countries have adopted Explicit Inflation Targeting comes from Hammond (2012). The data period is 1998 to 2010. We use annual data for all variables. When using macroeconomic data there is the potential problem of non-stationary data. Thus, we tested all used variables for unit roots. Here we used the Maddala and $\mathrm{Wu}$ (1999) Fisher test employing an ADF test. The result is that we are not plagued with non-stationary data. ${ }^{6}$ Thus, we do not have to check for cointegration but can stick to normal panel data models.

\section{Estimation Results}

\subsection{Central Bank Transparency and Inflation}

Now let us move to the estimation results. We have a panel data set with annual data for 13 years. That leads us to the question of what the right model for estimating the relationship between central bank transparency and inflation is. The pivotal question is whether there are time-invariant causes of inflation. Hayo (1998) argues that public attitudes towards inflation play a large role in explaining inflation differentials between countries. Let us assume that the inflation rate $p$ of country $i$ in year $t$ is explained by $\mathrm{m}$ time-varying explanatory variables $\mathrm{X}$ and $\mathrm{q}-\mathrm{m}$ time-invariant explanatory variables $\mathrm{W}$.

$$
\begin{gathered}
p_{i, t}=\beta_{0}+\sum_{k=1}^{m} \beta_{k} X_{k, i, t}+\sum_{v=m+1}^{q} \beta_{v} W_{v, i}+u_{i}+\varepsilon_{i, t} \\
t=1998, \ldots, 2012 ; i=1, \ldots, N
\end{gathered}
$$

Our assumption is that the inflation culture of a country does not change within a decade. Unfortunately, a direct measure for inflation aversion is not available for all countries in the data set. Thus, the whole effect of this omitted variable would end up in $u_{i}$. Inflation cultures could in turn influence the choice of a government to grant the central bank independence (Hayo (1998)). Then $u_{i}$ would be correlated with some of the regressors. This calls for a fixed effects model. By including a dummy for every country we can account for time-invariant inflation cultures. Within a fixed-effects panel data we can also control for other time-invariant phenomena that affect inflation. Furthermore, we clearly have to take worldwide effects into account in the full knowledge that the financial crisis, a.k.a. the Great Recession, is at the end

\footnotetext{
${ }^{6}$ The results are available upon request.
} 
of the estimation period. Also global effects like changes in oil prices influence inflation rates everywhere. Therefore, we include year dummies in our estimation. Thus, we essentially estimate the following equation:

$$
p_{i t}=\vartheta_{i}+\tau_{t}+\beta_{0}+\sum_{k=1}^{m} \beta_{k} X_{k i t}+\varepsilon_{i t}
$$

Here $\vartheta_{i}$ are country fixed effects and $\tau_{t}$ are time fixed effects. Given that the time-invariant explanatory variables $W_{v, i}$ from equation 8 and the fixed effects $u_{i}$ do not vary over time, they will drop out of the equation. The equation can then be estimated with OLS. Table 1 shows the estimation results for the determinants of inflation.

$\rightarrow$ Table 1 about here

Table 1 shows the result of a panel estimation including year and country fixed effects. The explanatory variables in the basic estimation are GDP growth, indices for cereal, crop, and food production, the real interest rate, money growth, the exchange rate change of the domestic currency towards the US dollar (direct quote), openness and the Eijffinger-Geraats transparency index. For some explanatory variables, lags are included as a result of the fact that changes in those variables do not immediately translate into higher prices. There is a significant negative relation between GDP growth and inflation which might be surprising at first sight. We argued before that GDP growth is a proxy for aggregated demand and should therefore have a positive impact on inflation. However, this is only true for demand sided shocks. In case of a supply side shock output and GDP would go down along with an increase in prices. This is a reasonable result considering the fact that a lot of emerging and developing countries are included in which supply shocks dominate demand shocks. Real interest rates are negatively related to inflation. The exchange rate has the expected positive impact on inflation. Thus, a depreciation leads to higher prices via imported inflation. Finally, openness seems to increase inflation which is surprising as we would expect that more open economies are also under stronger competition pressure. The variable of main interest is the transparency index. According to the first estimation, an increase in central bank transparency is associated with a significant decrease in the inflation rate. On the other hand, central bank independence turns out not to be relevant. ${ }^{7}$

Section 3 showed that there are several other factors that might be relevant for inflation. For instance, political instability was argued to be positively related to inflation. It could be the case that more stable political systems also have more transparent central banks which could blur the results. Thus, we have to control for a multitude of other variables. We try to capture instability by including Actors Engaging in Violence, the Political Terror Scale, Polity Fragmentation, and Political Stability. Given that fact that those variables are interconnected not all of them turn out to be significant. However, Polity Fragmentation is of utmost importance. Countries with a fragmented political system tend to have higher inflation rates. Furthermore, we include the Combined Polity Score that measures how democratic a system is. We do not find much evidence that democracy (higher values) leads to higher inflation rates. Moreover, we include all WGI variables. Thereby we can control for corruption. Countries with better corruption control on average have lower inflation. This is in line with the findings by Al-Marhubi (2000) who showed that countries facing severe corruption have less stable prices.

\footnotetext{
${ }^{7}$ One might argue that there was not much variation in central bank independence between 1998 and 2010. Albeit there was more variation in central bank transparency, the vast majority of countries (over $70 \%$ ) experienced changes in central bank independence.
} 
We also control for income equality by including the income share held by the top $20 \%$. However, income equality does not seem to matter here. We also include variables capturing government debt and deficits. Finally, we try to see whether employment protection or union density could affect the results. However, even after controlling for all those factors central bank transparency still has a significant negative impact on average inflation. Some might argue that it is not transparency but the adoption of Explicit Inflation Targeting (EIT) that brings inflation rates down. Therefore, we included a dummy variable for being an explicit inflation targeter. Even under this specification the effect of transparency does not vanish. When the dummy EIT is included but transparency is not, EIT still does not have a significant effect. This confirms that it is not EIT but transparency that helps to bring inflation down.

There might be concerns about potential endogeneity problems with respect to central bank transparency. Some might argue that it is central banks with low inflation rates that decide to increase their transparency. On the other hand, it might also be reasonable to assume that central banks with higher inflation rates increase their information provision with the aim of reducing inflation expectations. Either way we would have to conduct a robustness test. Thus, we employ a two stages fixed effects model. The study by Dincer and Eichengreen (2014) used several instrumental variables that are not perfectly suitable. They basically used all variables of the World Governance Indictors. However, we have already seen that some of these variables are directly correlated with inflation. Political Stability is the most problematic variable as there is overwhelming evidence in the literature that instability leads to higher inflation. Therefore, this study uses different instrumental variables. When we estimated the determinants of central bank transparency in some separate regressions, we found that bank assets as a percentage of GDP is negatively correlated and freedom of the press is positively correlated with central bank transparency. However, these two variables are not directly correlated with inflation which makes them good instruments. Neither are those two variables significant determinants of CBI or EIT.

Apart from that, there might be another issue. We already touched on the problems associated with GDP growth before. The challenge is that the direction of causation is not perfectly clear. There are strands in the literature that argue that high inflation rates are harmful for output growth. Kremer et al. (2013) recently found that output growth rates are lower if the inflation rate is higher than $2.5 \%$ in industrialised countries and $17 \%$ in developing countries. The detrimental impact of inflation on growth is also confirmed by López-Villavicencio and Mignon (2011). Baglan and Yoldas (2014) found that the threshold level for developing countries is at around $12 \%$. However, Vinayagathasan (2013) argues that the threshold level for Asian countries is around $5.43 \%$ and thus much lower than what the other papers estimated. In the light of the relation between GDP growth and inflation not being clear-cut, we could be plagued with reverse causality problems. In order to get rid of that issue, we could use an instrumental variable for GDP growth. Several variables might qualify as instruments. One approach would be to make use of the fact that energy is one of the main production factors. Therefore, higher energy consumption should be correlated with greater economic activity. Both overall energy consumption (Lee (2005)) and electrical consumption (Loungani and Sheets (1997)) are therefore reasonable proxies for GDP. In this study, we use the change in energy use (kg of oil equivalent per capita) as an instrumental variable for GDP growth. We instrument for current and lagged GDP growth with current and lagged energy consumption growth. Table 2 shows the results of the two stages least squares fixed effects estimations.

$\rightarrow$ Table 2 about here

In the first and second estimation, we only used one instrumental variable (bank assets) for central bank transparency. In the third and fourth estimation, we used both mentioned 
instruments. Models IV5 and IV6 use instrumental variables for both CBT and GDP growth. The F statistics of the first stages show that the selected instruments are relevant. The coefficient on central bank transparency has a wider range when the 2SLS approach is used but it is statistically significant in any instance. This puts more trust in the results. The results also show that the WGI variables would not be good instrumental variables as at least one variable is directly related to inflation.

Hitherto, we modelled the inflation rates as independent of those of the previous year(s). However, there is good reason for using a dynamic panel data model assuming that there is persistence in inflation rates. Then the model would look like this:

$$
p_{i t}=\vartheta_{i}+\tau_{t}+\beta_{0}+\beta_{1} p_{i, t-1}+\sum_{k=2}^{m} \beta_{k} X_{k i t}+u_{i}+\varepsilon_{i t}
$$

An estimation of this dynamic panel data model within a fixed effects framework would lead to inconsistent estimations due to Nickell's (1981) well known "dynamic panel bias". In this instance, the coefficient for the lagged variable would be underestimated. The bias decreases with the number of time periods. However, with only 13 years in the sample the bias is substantial and we cannot use an FE estimator. The problem would be aggravated if the lagged inflation rate is also correlated with some other independent variables. Then the coefficients of the respective regressors might also be biased (Baum (2006)). For instance, it could be the case that high inflation rates lead central banks to increase their transparency. This calls for a panel GMM model in the sense of Arellano and Bond (1991). The proposition by Kiviet (1995) to use an FE model and correct for the bias is not appropriate in this context for two reasons. Firstly, we would need an unbalanced panel which we do not have. Secondly, this approach does not correct for the potential problem of correlation between the lagged variable and other explanatory variables.

Thus, we stick with the Blundell and Bond (1998) system GMM approach and treat the lagged inflation rate and CBT as endogenous and use lagged levels of these variables as instruments. For system GMM we need two conditions to hold. The first one is about serial and cross-section correlation between the lagged dependent variable and the change in the error term:

$$
E\left(p_{i, t-w} \Delta \varepsilon_{i, t}\right)=0 \quad \forall i, t \text { and } w=2, \ldots, T
$$

The basic idea of the Arellano and Bond approach is to instrument the lagged dependent variable with further lags of the dependent variable. In our case, we instrument the lagged inflation rate with the inflation rate two years ago. The assumption made in equation 11 can be tested with the Arellano and Bond (1991) test. For this specific case there must not be AR(2) serial correlation because otherwise the second lag of the inflation rate could not work as an appropriate instrumental variable. System GMM requires another assumption:

$$
E\left(\Delta p_{i, t-w}\left[\vartheta_{i}+\varepsilon_{i, t}\right]\right)=0 \quad \forall i, t \text { and } w=2, \ldots, T
$$

This assumption basically says that lagged changes of the dependent variable must not be correlated with the country specific fixed effects. There is no straightforward test for this assumption so we have to use our intuition. We suppose that the current level of inflation is not clearly related to changes in the inflation rate. For instance, it is not necessarily the case that countries with higher inflation compared to the other countries will constantly strive for disinflations to reduce average inflation. As we argued before, it is also conceivable that countries are hardly inflation averse and will therefore always have higher inflation rates than other countries. Thus, it seems that this assumption should be satisfied. 
Apart from lagged values of the endogenous variables, we include some additional instrumental variables. These are the lagged nominal interest rate and lagged population growth as we would expect that they can explain lagged inflation rates. We treat the other explanatory variables as exogenous so they can instrument themselves. The additional variables are only included in levels but not as first differences. For the endogenous variables we use the second lag of levels and first differences as instrumental variables. We also include yearly dummies which is usually recommended when using system or difference GMM models. The standard errors of the estimation are robust to heteroscedasticity and autocorrelation. Table 3 shows the results of the dynamic panel data estimations.

$\rightarrow$ Table 3 about here

The results show that there is persistence in inflation rates even though the coefficient on the lagged inflation is not statistically significant from zero in all estimations when we control for other factors. Real interest rates have a negative impact and money growth and depreciations of the local currency have a positive impact on inflation. Government deficits are related to higher inflation rates. The other variables do not seem to matter much. Coming back to the role of central bank transparency: in each specification CBT does have a positive influence on price stability. The estimated coefficient for the transparency index is in each case significantly different from zero at least at the 10 percent level of significance. Thus, we also found a decreasing effect of transparency on inflation in this setting. The phenomenon did not disappear once we controlled for persistence in inflation rates and other determinants of inflation. However, it is also necessary to check the properties of the system GMM models. There are two criteria that are relevant: autocorrelation of the error terms and exogeneity of the instruments. The Arellano-Bond test examines autocorrelation of the differenced residuals. First-order autocorrelation would not be problematic but second order autocorrelation would. The results of the Arellano Bond test are presented at the bottom of the table. The results show that the null hypothesis of no $\operatorname{AR}(2)$ in differenced residuals cannot be rejected. This is a good result given the fact that higher order autocorrelation would harm the moment conditions of this approach. The other requirement is exogeneity of the employed instruments. Here we employ the Hansen J statistic that tests the overidentification restrictions. The null hypothesis of this test is that the instruments are exogenous. The null hypothesis is not rejected in any case. Thus, even this condition is met.

To sum up, there is empirical evidence for a diminishing effect of central bank transparency on inflation in various specifications. We controlled for several other causes of inflation in both a non-dynamic and a dynamic setting. Thereby, the study clearly extended previous analyses. The models showed that central bank transparency can have a positive impact in economic terms which might be a rationale as to why so many central banks expanded their information distribution.

\subsection{Central Bank Transparency and Inflation Volatility}

Apart from the relation between transparency and inflation, we are also interested in the question of whether transparency can also be beneficial in terms of lower inflation volatility. The main question here is whether transparency only leads to more stable inflation rates through lower inflation rates or whether transparency has an additional lowering effect on inflation variability. When we estimate the determinants of inflation volatility, we basically follow the same approach that we used in Section 4.1. We use a panel data model with time and country 
fixed effects where the dependent variable is the respective measure for inflation variability $\left(\varphi_{i t}\right)$.

$$
\varphi_{i t}=\vartheta_{i}+\tau_{t}+\beta_{0}+\sum_{k=1}^{m} \beta_{k} X_{k i t}+\varepsilon_{i t}
$$

However, we might assume that the effect of CBT on inflation volatility is stronger the higher inflation rates are. Accordingly, we include an interaction term in order to capture this effect. However, it is notoriously difficult to measure models with interaction terms. Thus, we follow the instructions by Balli and Sørensen (2013). They argue that one should not use simple interaction terms between metric variables (here CBT and inflation) but rather interactions between differences from country means for the respective variables. Furthermore, we also assume that the positive effect of CBT is not linear but it diminishes the higher the level of CBT is. Let us suppose $C B T_{i t}$ is the amount of central bank transparency in country $i$ in year $t$. Then $\overline{C B T_{l}}$ is the average central bank transparency of country $i$ over the entire estimation period. $\left(C B T_{i t}-\overline{C B T_{l}}\right)$ is, therefore, the difference of CBT from its mean over time in a particular country $i$. We do the same for the squared CBT value. Please note that we squared CBT initially, compute the time average for each country, and then subtract $C B T_{i t}^{2}$ from the respective country mean. Thus, $\left(C B T_{i t}^{2}-\overline{C B T_{l}^{2}}\right)$ can, of course, be negative. We use the same approach for inflation (remember that $p_{i t}$ is the inflation rate in country $i$ in year $t$ ).

$$
\begin{gathered}
\varphi_{i t}=\vartheta_{i}+\tau_{t}+\beta_{0}+\beta_{1} p_{i t}+\beta_{2} C B T_{i t}+\beta_{3} C B T_{i t}^{2}+\beta_{4}\left(p_{i t}-\bar{p}_{l}\right)\left(C B T_{i t}-\overline{C B T_{l}}\right)+ \\
\beta_{4}\left(p_{i t}-\bar{p}_{l}\right)\left(C B T_{i t}^{2}-\overline{C B T_{l}^{2}}\right)+\sum_{k=1}^{m} \beta_{k} X_{k i t}+\varepsilon_{i t}
\end{gathered}
$$

According to Balli and Sørensen (2013), this is the preferable specification in order to prevent spurious regressions. Of course, we conduct several robustness checks. Firstly, we use the interaction term between current CBT and lagged inflation $\left(\left(p_{i t-1}-\bar{p}_{l}\right)\left(C B T_{i t}-\overline{C B T_{l}}\right)\right.$. Secondly, we create a dummy for countries with inflation rates of more than ten percent. Then we interact this dummy variable with CBT. Thirdly, we also used the plain interaction terms between inflation and CBT even though it is not recommended. The main problem is, of course, that it makes the interpretation of coefficients terribly difficult, especially in a case where zero is not a reasonable value for any of the two interacted variables. We also control for several other factors with a potential impact on inflation volatility that have been put forth by other scholars. The main results are presented in Table 4. For the sake of brevity, we only present the estimation results for one measure of inflation volatility but discuss the others briefly. ${ }^{8}$

$\rightarrow$ Table 4 about here

Initially, the estimations show that CBT decreases inflation variability when inflation is not included or when only the inflation rate of the current period is included as an explanatory variable. However, CBT does not have a significant impact if both current and lagged inflation

\footnotetext{
${ }^{8}$ The other results are available upon request.
} 
are included. Then we control for several other factors that have been found as potential triggers of inflation volatility in the past. Here we include several measures of volatility of other macroeconomic variables. These are volatility of exchange rate growth (local currency per US Dollar), GDP growth, M1 growth, M2 growth, and M3 growth. Due to the lack of data and the correlation between the volatility of the three money growth measures, we only include M2 growth volatility in most estimations. Apart from that, we include GDP growth, real GDP per capita, and a bunch of political variables. Volatility of money growth is clearly positively related to inflation volatility which is not surprising. Exchange rate growth volatility reduces inflation uncertainty but the effect is rather low in economic terms. At the same time, there is some mild evidence that more open countries have less volatile inflation rates. Also more developed countries (higher GDP per capita) tend to face lower inflation uncertainty. It is important to note that there are far fewer countries involved in these estimations as the data for many variables was not readily available. Thus, the analysis mainly applies to more advanced countries. The Polity 2 variable indicates that more democratic countries tend to have less fluctuant inflation rates. The main question is what effect transparency has. In most specifications we find CBT to have a diminishing effect on inflation volatility. The effect gets lower the higher the amount of CBT is. This effect is captured by the interaction terms. Thus, the effect is contingent upon the level of inflation. The impact of CBT is stronger the larger the current amount of inflation is. However, we can also interpret the result differently. The adverse effect of inflation on inflation volatility is lower the more transparent central banks are. As mentioned before, we will not show the results for the other measures of inflation volatility in detail. However, we can confirm that the encountered effect of transparency is also present for most other measures. We only find difficulties in getting meaningful results for the GARCH(1,1) model. However, we hardly find any significant determinants of inflation volatility when it is measured by GARCH models. As robustness checks we use an interaction term between a dummy for plus ten percent inflation countries and CBT and also the product of lagged inflation with current CBT. When using the first approach, we find that the diminishing effect of CBT on inflation is only present for countries with inflation rates higher than ten percent. The impact of CBT is much lower in statistical terms when we use the second approach. Still this robustness check makes our results more trustworthy. Overall, the fit of the models is very good which is proven by the relatively high adjusted $\mathrm{R}^{2}$.

One might be concerned about possible multicollinearity between inflation and CBT given that we showed that CBT tends to reduce average inflation. However, both variables are only slightly negatively correlated when we do not control for other variables. We computed the average variance inflation factors (VIF) for all regressions. There are some cases where the mean VIF is well above 10. However, this is partly the result of the VIF of the country dummies. When we exclude the country dummies, there is hardly any case where the mean VIF is above 10. And even if there was some multicollinearity problem, this would not affect the unbiasedness and consistency of the ordinary least squares approach.

It might be reasonable to assume that there is persistence in inflation volatility. Here we would also need to use a system GMM model that was employed in section 4.1. However, it was relatively difficult to find specifications that meet all requirements given that the number of countries with available data is limited. In the respective models there is hardly any significant effect of central bank transparency when we control for lagged inflation volatility and current and lagged inflation. For the sake of brevity, we decided not to present the results in detail but just to discuss them briefly. Overall, there are almost no significant variables apart from inflation and lagged inflation volatility in the dynamic version. Thus, this is a big caveat that we only found a decreasing effect of central bank transparency on inflation volatility in the nondynamic version. 
The results are still meaningful as the analysis goes well beyond Dincer and Eichengreen (2014) who only included a handful of explanatory variables. They did not find any decreasing effect of CBT on inflation variability when they controlled for inflation. We, on the other hand, controlled for many more variables and still found evidence that CBT diminished inflation volatility.

\section{Conclusions}

The intention of this paper was to analyse the relationship between central bank transparency and inflation. The literature review clearly showed that theory cannot deliver a concise answer to this question. Some papers argued that transparency should have a dampening effect on prices. Other articles argued the converse saying that transparency leads to higher inflation rates. Several empirical studies have been conducted to solve this puzzle. Most studies with the exception of those of Demertzis and Hughes Hallett (2007) came to the conclusion that central bank transparency reduces average inflation. However, these papers suffered from certain shortcomings. One of the major problems was that these papers did not take other causes of inflation into account. That could lead to wrong inference if too much is attributed to central bank transparency. It could well be the case that more transparent central banks are simply more conservative than other central banks e.g. by charging higher interest rates on their central bank credits.

Therefore, we employed a panel data set with information on the Eijffinger-Geraats central bank transparency index to figure out the impact of monetary policy openness while controlling for other inflation causes at the same time. Within a fixed effects model a significant negative effect of transparency on inflation manifested. Then we did some robustness checks by employing a two stages least squares approach and including further regressors. Even under these circumstances central bank transparency had a diminishing effect on prices. Finally, we employed a dynamic linear panel model to control for persistence in inflation rates. Within a system GMM we still found transparency to be a significant determinant of inflation. In the second part of the empirical analysis we looked at the determinants of inflation variability. We found central bank transparency to have a diminishing effect on inflation volatility that is contingent upon inflation. The higher inflation is, the stronger the effect of central bank transparency on inflation stability. However, we did not find a significant impact of central bank transparency on inflation volatility in the dynamic panel data model. Still the results are economically important.

Of course, the results should not lead to the conclusion that transparency increases are positive without any restrictions. It is also not perfectly clear where the entire effect comes from. However, it is a politically important result that central bank transparency can help stabilise prices, and it emphasises the role of central bank speaking in the era of fiat money where monetary policy is mainly about trust and credibility. 


\section{References}

Aisen, A., \& Veiga, F. J. (2006). Does political instability lead to higher inflation? A panel data analysis. Journal of Money, Credit, and Banking, 38(5), 1379-1389.

Aisen, A., \& Veiga, F. J. (2008). Political instability and inflation volatility. Public Choice, 135(3-4), 207-223.

Al-Marhubi, F. (1997). A note on the link between income inequality and inflation. Economics Letters, 55(3), 317-319.

Al-Marhubi, F. A. (2000). Corruption and inflation. Economics Letters, 66(2), 199-202.

Apergis, N. (2004). Inflation, output growth, volatility and causality: evidence from panel data and the G7 countries. Economics Letters, 83(2), 185-191.

Arellano, M., \& Bond, S. (1991). Some tests of specification for panel data: Monte Carlo evidence and an application to employment equations. The Review of Economic Studies, 58(2), 277-297.

Baglan, D., \& Yoldas, E. (2014). Non-linearity in the inflation-growth relationship in developing economies: Evidence from a semiparametric panel model. Economics Letters, 125(1), 93-96.

Bahmani-Oskooee, M., \& Miteza, I. (2006). Are devaluations contractionary? Evidence from panel cointegration. Economic Issues, 11(1).

Balli, H. O., \& Sørensen, B. E. (2013). Interaction effects in econometrics. Empirical Economics, 45(1), 583-603.

Batchelor, R., \& Dua, P. (1996). Empirical measures of inflation uncertainty: a cautionary note. Applied Economics, 28(3), 333-341.

Baum, C. F. (2006). An introduction to modern econometrics using Stata. Stata press.

Bleaney, M., \& Fielding, D. (2002). Exchange rate regimes, inflation and output volatility in developing countries. Journal of Development Economics, 68(1), 233-245.

Blundell, R., \& Bond, S. (1998). Initial conditions and moment restrictions in dynamic panel data models. Journal of Econometrics, 87(1), 115-143.

Bowdler, C., \& Nunziata, L. (2007). Trade union density and inflation performance: Evidence from OECD panel data. Economica, 74(293), 135-159.

Campa, J. M., \& Goldberg, L. S. (2005). Exchange rate pass-through into import prices. Review of Economics and Statistics, 87(4), 679-690.

Catao, L. A., \& Terrones, M. E. (2005). Fiscal deficits and inflation. Journal of Monetary Economics, 52(3), 529-554. 
Cecchetti, S. G., \& Krause, S. (2002). Central bank structure, policy efficiency, and macroeconomic performance: exploring empirical relationships. Federal Reserve Bank of St. Louis Review, 84(July/August 2002).

Chortareas, G. E., Stasavage, D., \& Sterne, G. (2001). Does it pay to be transparent? International evidence from central bank forecasts. Bank of England Working Paper 143.

Chou, W. L., \& Chao, C. C. (2001). Are currency devaluations effective? A panel unit root test. Economics Letters, 72(1), 19-25.

Cochrane, J. H. (2001). Long-Term Debt and Optimal Policy in the Fiscal Theory of the Price Level. Econometrica, 69(1), 69-116.

Cournède, B., \& Minegishi, M. (2009). The role of transparency in the conduct of monetary policy (No. 724). OECD Economics Department Working Paper.

Crowe, C., \& Meade, E. E. (2007). The evolution of central bank governance around the world. The Journal of Economic Perspectives, 21(4), 69-90.

Crowe, C., \& Meade, E. E. (2008). Central bank independence and transparency: Evolution and effectiveness. European Journal of Political Economy, 24(4), 763-777.

Cukierman, A. (2002). Are contemporary central banks transparent about economic models and objectives and what difference does it make?. Federal Reserve Bank of St. Louis Review, 84(July/August 2002).

Cukierman, A., Edwards, S., \& Tabellini, G. (1992a). Seigniorage and political instability. American Economic Review, 82(3), 537-555.

Cukierman, A., Web, S. B., \& Neyapti, B. (1992b). Measuring the independence of central banks and its effect on policy outcomes. The World Bank Economic Review, 6(3), 353398.

Daniels, J. P., Nourzad, F., \& VanHoose, D. D. (2005). Openness, central bank independence, and the sacrifice ratio. Journal of Money, Credit, and Banking, 37(2), 371-379.

De Grauwe, P., \& Polan, M. (2005). Is Inflation Always and Everywhere a Monetary Phenomenon?. The Scandinavian Journal of Economics, 107(2), 239-259.

Demertzis, M., \& Hallett, A. H. (2007). Central bank transparency in theory and practice. Journal of Macroeconomics, 29(4), 760-789.

Desai, R. M., Olofsgård, A., \& Yousef, T. M. (2003). Democracy, inequality, and inflation. American Political Science Review, 97(03), 391-406.

Dincer, N. N., \& Eichengreen, B. (2014). Central Bank Transparency and Independence: Updates and New Measures. International Journal of Central Banking, 10(1), 189-259.

Ding, Z., Granger, C. W., \& Engle, R. F. (1993). A long memory property of stock market returns and a new model. Journal of Empirical Finance, 1(1), 83-106. 
Eijffinger, S. C., \& Geraats, P. M. (2006). How transparent are central banks?. European Journal of Political Economy, 22(1), 1-21.

Eijffinger, S. C., Hoeberichts, M., \& Schaling, E. (2000). Why money talks and wealth whispers: Monetary uncertainty and mystique. Journal of Money, Credit and Banking, 218-235.

Fatás, A., Mihov, I., \& Rose, A. K. (2007). Quantitative goals for monetary policy. Journal of Money, Credit and Banking, 39(5), 1163-1176.

Frankel, J. A. (2011). Monetary Policy in Emerging Markets, Vol. 3B. In: Friedman, B. M., \& Woodford, M. (Eds.). (2010). Handbook of Monetary Economics (Vol. 3B). Elsevier., 1439-1520.

Frankel, J., Parsley, D., \& Wei, S. J. (2012). Slow pass-through around the world: a new import for developing countries?. Open Economies Review, 23(2), 213-251.

Friedman, M. (1970). Counter-Revolution in Monetary Theory. Wincott Memorial Lecture, Institute of Economic Affairs. IEA Occasional Paper, 33.

Fry, M., Julius, D., Mahadeva, L., Roger, S., \& Sterne, G. (2000). Key issues in the choice of monetary policy framework. Monetary policy frameworks in a global context, London: Routledge, 2000: 2-18.

Gasiorowski, M. J. (2000). Democracy and Macroeconomic Performance in Underdeveloped Countries An Empirical Analysis. Comparative Political Studies, 33(3), 319-349.

Geraats, P. M. (2005). Transparency and reputation: The publication of central bank forecasts. Topics in Macroeconomics, 5(1).

Glosten, L. R., Jagannathan, R., \& Runkle, D. E. (1993). On the relation between the expected value and the volatility of the nominal excess return on stocks. The Journal of Finance, 48(5), 1779-1801.

Gruben, W. C., \& McLeod, D. (2002). Capital account liberalization and inflation. Economics Letters, 77(2), 221-225.

Gruben, W. C., \& McLeod, D. (2004). The openness-inflation puzzle revisited. Applied Economics Letters, 11(8), 465-468.

Grüner, H. P. (2002). How much should central banks talk?: A new argument. Economics Letters, 77(2), 195-198.

Hammond, G. (2010). State of the Arte of Inflation Targeting. In Bank of England. CCBS Handbook.

Hayo, B. (1998). Inflation culture, central bank independence and price stability. European Journal of Political Economy, 14(2), 241-263. 
Hayo, B., \& Hefeker, C. (2002). Reconsidering central bank independence. European Journal of Political Economy, 18(4), 653-674.

Hibbs, D. A. (1977). Political parties and macroeconomic policy. American Political Science Review, 71(04), 1467-1487.

Higgins, M. L., \& Bera, A. K. (1992). A class of nonlinear ARCH models. International Economic Review, 137-158.

Hughes Hallett, A., \& Libich, J. (2006). Central Bank Independence, Accountability and Transparency: Complements or Strategic Substitutes? (No. 5470). CEPR Discussion Papers.

IMF (1996). The Rise and Fall of Inflation - Lessons from the Postwar Experience. In International Monetary Fund Research Dept., editor, World Economic Outlook: A Survey by the Staff of the International Monetary Fund, pages 100-131. International Monetary Fund, Washington, D.C.

Kiviet, J. F. (1995). On bias, inconsistency, and efficiency of various estimators in dynamic panel data models. Journal of Econometrics, 68(1), 53-78.

Kremer, S., Bick, A., \& Nautz, D. (2013). Inflation and growth: new evidence from a dynamic panel threshold analysis. Empirical Economics, 44(2), 861-878.

Kydland, F. E., \& Prescott, E. C. (1977). Rules rather than discretion: The inconsistency of optimal plans. The Journal of Political Economy, 85(3), 473-491.

Lee, C. C. (2005). Energy consumption and GDP in developing countries: a cointegrated panel analysis. Energy Economics, 27(3), 415-427.

Levin, A. T., Natalucci, F. M., \& Piger, J. M. (2004). The macroeconomic effects of inflation targeting. Federal Reserve Bank of St. Louis Review, 86(July/August 2004).

López-Villavicencio, A., \& Mignon, V. (2011). On the impact of inflation on output growth: Does the level of inflation matter?. Journal of Macroeconomics, 33(3), 455-464.

Loungani, P., \& Sheets, N. (1997). Central bank independence, inflation, and growth in transition economies. Journal of Money, Credit, and Banking, 381-399.

Lucchetti, K., \& Balietti, S. (2011). The gig package. (online available at: http://fossies.org/windows/misc/gretl-1.10.1-win32.zip/gretl/functions/gig/gig.pdf)

Maddala, G. S., \& Wu, S. (1999). A comparative study of unit root tests with panel data and a new simple test. Oxford Bulletin of Economics and statistics, 61(S1), 631-652.

Mishkin, F. S. (2004). Can central bank transparency go too far? (No. w10829). National Bureau of Economic Research.

Narayan, P. K., \& Narayan, S. (2007). Is devaluation expansionary or contractionary? Empirical evidence from Fiji. Applied Economics, 39(20), 2589-2598. 
Nelson, D. B. (1991). Conditional heteroskedasticity in asset returns: A new approach. Econometrica: Journal of the Econometric Society, 59(2), 347-370.

Nickell, S. (1981). Biases in dynamic models with fixed effects. Econometrica: Journal of the Econometric Society, 1417-1426.

Nordhaus, W. D. (1975). The political business cycle. The Review of Economic Studies, 42(4), 169-190.

Rogoff, K. (1985). The optimal degree of commitment to an intermediate monetary target. The Quarterly Journal of Economics, 100(4), 1169-1189.

Rolnick, A. J., \& Weber, W. E. (1997). Money, inflation, and output under fiat and commodity standards. Journal of Political Economy, 105(6), 1308-1321.

Sachsida, A., Carneiro, F. G., \& Loureiro, P. R. (2003). Does greater trade openness reduce inflation? Further evidence using panel data techniques. Economics Letters, 81(3), 315319.

Schaling, E., \& Nolan, C. (1998). Monetary policy uncertainty and inflation: The role of central bank accountability. De Economist, 146(4), 585-602.

Sibert, A. (2002). Monetary policy with uncertain central bank preferences. European Economic Review, 46(6), 1093-1109.

Siklos, P. L. (2003). Assessing the Impact of Changes in Transparency and Accountability at the Bank of Canada. Canadian Public Policy/Analyse de Politiques, 279-299.

Sørsensen, J. R. (1991): Political uncertainty and macroeconomic performance. Economics Letters, 37(4), 377-381.

Tas, B. K. O., \& Ertugrul, H. M. (2013). Effect of Inflation Targeting on Inflation Uncertainty: A SWARCH Analysis. Australian Economic Review, 46(4), 444-459.

Vinayagathasan, T. (2013). Inflation and economic growth: A dynamic panel threshold analysis for Asian economies. Journal of Asian Economics, 26, 31-41.

Walsh, C. E. (1999). Announcements, inflation targeting and central bank incentives. Economica, 66(262), 255-269.

Westelius, N. J. (2005). Discretionary monetary policy and inflation persistence. Journal of Monetary Economics, 52(2), 477-496.

Westelius, N. J. (2009). Imperfect transparency and shifts in the central bank's output gap target. Journal of Economic Dynamics and Control, 33(4), 985-996.

Willard, L. B. (2012). Does inflation targeting matter? A reassessment. Applied Economics, 44(17), 2231-2244. 
Yörükoglu, M. (2010). Difficulties in inflation measurement and monetary policy in emerging market economies. BIS Papers, 49, 369-389.

Zakoian, J. M. (1994). Threshold heteroskedastic models. Journal of Economic Dynamics and Control, 18(5), 931-955. 


\section{Appendix}

Table 1: Determinants of Inflation

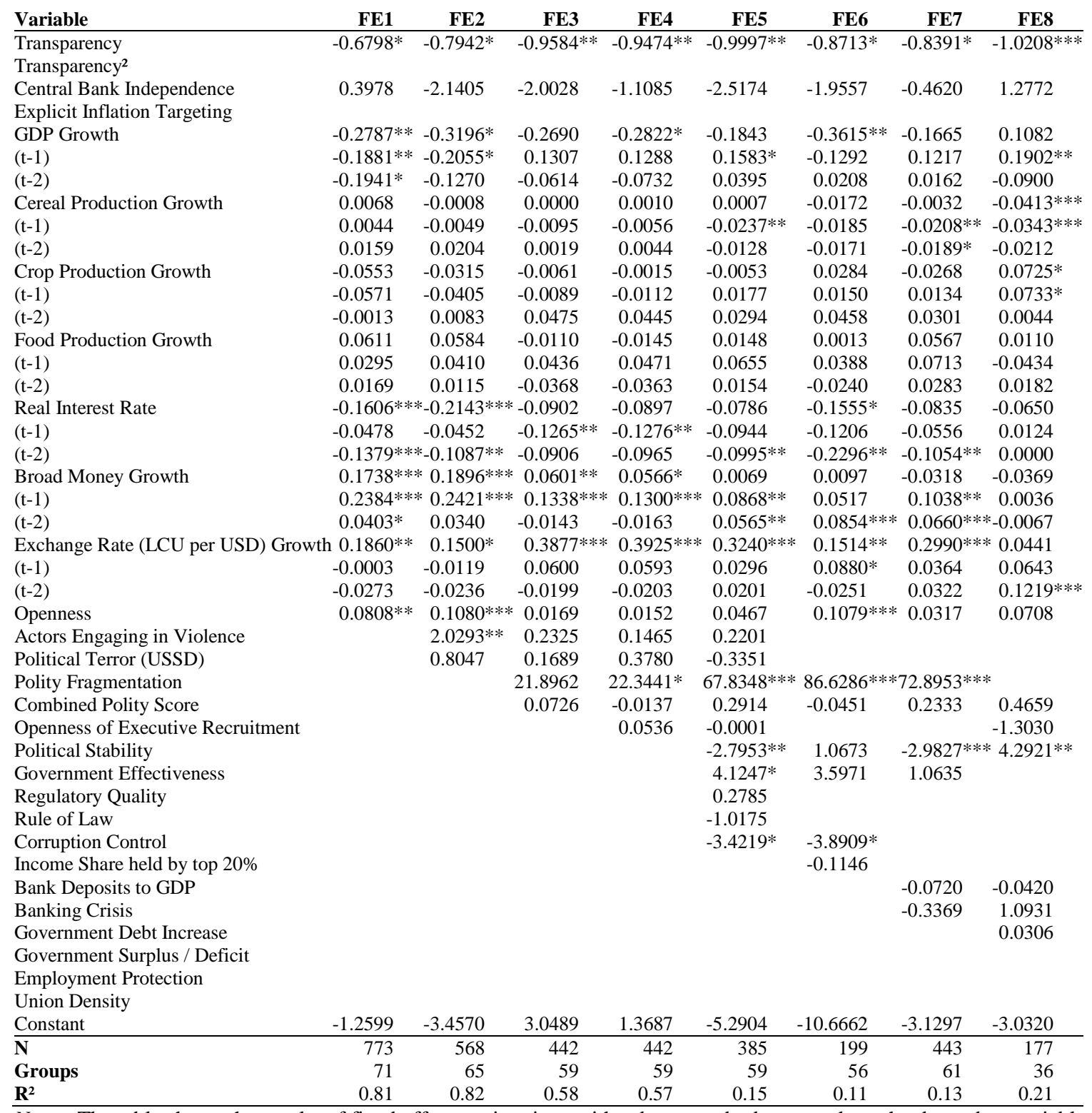

Notes: The table shows the results of fixed effects estimations with robust standard errors where the dependent variable is CPI inflation. The asterisks indicate whether a coefficient is significantly different from zero at the $10 \%$ (one asterisk), $5 \%$ (two asterisks) or $1 \%$ (three asterisks) significance level. 
Table 1: Determinants of Inflation (continued)

\begin{tabular}{|c|c|c|c|c|c|c|c|}
\hline Variable & FE9 & FE10 & FE11 & FE12 & FE13 & FE14 & FE15 \\
\hline Transparency & $-0.8932 * *$ & $-0.4415^{*}$ & $-2.3983^{* * *}$ & $-2.1567 *$ & $-2.7766^{* * *}$ & $-2.7666^{* * *}$ & \\
\hline Transparency ${ }^{2}$ & & & $0.0972 * *$ & $0.1168 *$ & $0.1489 * *$ & $0.1488 * *$ & \\
\hline Central Bank Independence & 4.8549 & 3.4124 & $5.3649 * *$ & -3.9840 & -0.7459 & -0.7223 & -0.8188 \\
\hline Explicit Inflation Targeting & & & & & & -0.2044 & -1.3216 \\
\hline GDP Growth & $0.1551 *$ & $-0.2466^{* * * *}$ & $-0.2855 * * *$ & -0.1525 & -0.1399 & -0.1405 & -0.1470 \\
\hline$(\mathrm{t}-1)$ & 0.1466 & 0.0608 & $0.2189 *$ & $0.1644 *$ & 0.1323 & 0.1326 & 0.1286 \\
\hline$(\mathrm{t}-2)$ & -0.1099 & $0.1954^{*}$ & 0.1056 & -0.0912 & 0.0209 & 0.0266 & 0.0369 \\
\hline Cereal Production Growth & $-0.0446 * * *$ & $-0.0198 *$ & -0.0137 & 0.0098 & -0.0018 & -0.0018 & -0.0036 \\
\hline$(\mathrm{t}-1)$ & $-0.0417 * *$ & -0.0166 & $-0.0197 *$ & -0.0171 & $-0.0207 * *$ & $-0.0206^{* *}$ & $-0.0195 *$ \\
\hline$(\mathrm{t}-2)$ & -0.0177 & -0.0072 & -0.0117 & $-0.0190 * *$ & -0.0174 & -0.0173 & $-0.0178 *$ \\
\hline Crop Production Growth & $0.1131 * * *$ & $0.0674 * * *$ & $0.0680 * * *$ & -0.0184 & -0.0259 & -0.0264 & -0.0327 \\
\hline$(\mathrm{t}-1)$ & $0.0908^{*}$ & 0.0137 & $0.0655^{*}$ & 0.0392 & 0.0226 & 0.0219 & 0.0062 \\
\hline$(\mathrm{t}-2)$ & -0.0015 & 0.0010 & $0.0415 *$ & 0.0310 & 0.0350 & 0.0334 & 0.0220 \\
\hline Food Production Growth & -0.0523 & -0.0559 & $-0.0603 * *$ & 0.0483 & 0.0434 & 0.0430 & $0.0668 *$ \\
\hline$(\mathrm{t}-1)$ & -0.0754 & -0.0122 & -0.0518 & 0.0470 & 0.0541 & 0.0533 & 0.0821 \\
\hline$(\mathrm{t}-2)$ & 0.0030 & -0.0496 & $-0.0775 *$ & 0.0443 & 0.0197 & 0.0213 & 0.0362 \\
\hline Real Interest Rate & -0.1083 & -0.0087 & -0.0540 & $-0.1501 * *$ & $-0.1029 *$ & $-0.1017 *$ & -0.0746 \\
\hline$(\mathrm{t}-1)$ & 0.1119 & 0.0065 & -0.0449 & $-0.1403^{* *}$ & -0.0704 & -0.0702 & -0.0445 \\
\hline$(\mathrm{t}-2)$ & -0.0108 & -0.0663 & $-0.1143 *$ & $-0.1542 * *$ & $-0.1177 * * *$ & $-0.1180 * * *$ & $-0.1009 * *$ \\
\hline Broad Money Growth & -0.0279 & $-0.0360^{*}$ & -0.0122 & $-0.0523^{*}$ & -0.0335 & -0.0327 & -0.0324 \\
\hline$(\mathrm{t}-1)$ & 0.0007 & 0.0006 & 0.0052 & $0.0853 * *$ & $0.1057^{* *} *$ & $0.1056^{* *} *$ & $0.1020 * *$ \\
\hline$(\mathrm{t}-2)$ & -0.0180 & -0.0104 & 0.0002 & 0.0049 & $0.0672 * * *$ & $0.0676^{* * *}$ & $0.0637 * *$ \\
\hline Exchange Rate (LCU per USD) Growth & h 0.0186 & -0.0053 & -0.0185 & $0.2230 * * *$ & $0.2963 * * *$ & $0.2971^{* * * *}$ & $0.3055^{* * * *}$ \\
\hline$(\mathrm{t}-1)$ & $0.0663 *$ & $0.0715^{* * *} *$ & $0.0593 * *$ & $0.1865 * * *$ & 0.0318 & 0.0326 & 0.0377 \\
\hline$(\mathrm{t}-2)$ & $0.1396 * * *$ & $=0.0299$ & -0.0069 & $0.0723 * *$ & 0.0296 & 0.0289 & 0.0362 \\
\hline Openness & 0.0490 & 0.0240 & 0.0347 & 0.0260 & 0.0267 & 0.0252 & 0.0289 \\
\hline \multicolumn{8}{|l|}{ Actors Engaging in Violence } \\
\hline \multicolumn{8}{|l|}{ Political Terror (USSD) } \\
\hline Polity Fragmentation & & & & $39.0621 * *$ & $73.5544 * * *$ & $73.3116^{* * *}$ & $72.8042 * * *$ \\
\hline Combined Polity Score & 0.4774 & $-0.7609^{* *}$ & -0.3120 & 0.3822 & 0.2353 & 0.2340 & 0.2267 \\
\hline \multicolumn{8}{|l|}{ Openness of Executive Recruitment } \\
\hline Political Stability & -1.4036 & -0.7515 & -0.6035 & $-3.0188 * *$ & $-2.6575^{* *}$ & $-2.6537 * *$ & $-2.7050 * *$ \\
\hline Government Effectiveness & $4.6546^{* *}$ & 0.6020 & -0.1347 & 2.7098 & & & \\
\hline \multicolumn{8}{|l|}{ Regulatory Quality } \\
\hline \multicolumn{8}{|l|}{ Rule of Law } \\
\hline \multicolumn{8}{|l|}{ Corruption Control } \\
\hline \multicolumn{8}{|l|}{ Income Share held by top $20 \%$} \\
\hline Bank Deposits to GDP & -0.0493 & 0.0114 & 0.0135 & $-0.0811 * *$ & -0.0695 & $-0.0752^{*}$ & $-0.0762 *$ \\
\hline Banking Crisis & 0.4268 & 0.2458 & -0.0228 & -0.4474 & -0.6244 & & \\
\hline Government Debt Increase & 0.0081 & 0.0000 & & & & & \\
\hline Government Surplus / Deficit & $0.0000 * * *$ & & 0.0000 & 0.0000 & & & \\
\hline Employment Protection & & -1.4851 & & & & & \\
\hline Union Density & & & -0.0491 & & & & \\
\hline Constant & -2.5110 & $15.5882 * *$ & $17.9792 * *$ & 6.7326 & 2.1599 & 2.4784 & -7.3539 \\
\hline $\mathbf{N}$ & 155 & 80 & 85 & 325 & 443 & 443 & 443 \\
\hline Groups & 32 & 18 & 14 & 54 & 61 & 61 & 61 \\
\hline $\mathbf{R}^{2}$ & 0.24 & 0.36 & 0.44 & 0.47 & 0.13 & 0.13 & 0.12 \\
\hline
\end{tabular}

Notes: The table shows the results of fixed effects estimations with robust standard errors where the dependent variable is CPI inflation. The asterisks indicate whether a coefficient is significantly different from zero at the $10 \%$ (one asterisk), $5 \%$ (two asterisks) or $1 \%$ (three asterisks) significance level. 
Table 2: Two-Stages Least Squares Estimations

\begin{tabular}{|c|c|c|c|c|c|c|}
\hline Variable & IV1 & IV2 & IV3 & IV4 & IV5 & IV6 \\
\hline Transparency & $-1.6139^{*}$ & $-7.3313^{*}$ & $-2.4362 *$ & $-4.8183^{*}$ & $-1.8655^{* *}$ & $-6.6181 * *$ \\
\hline Explicit Inflation Targeting & -0.8612 & 12.2642 & 0.8680 & 7.5834 & -0.4176 & 10.8943 \\
\hline Central Bank Independence & 0.3139 & -0.7584 & 0.3151 & -1.7655 & 0.6343 & -0.8110 \\
\hline GDP Growth & $-0.1731^{*}$ & -0.1469 & -0.2138 & -0.1683 & -0.1065 & -0.1448 \\
\hline$(\mathrm{t}-1)$ & -0.0032 & 0.2021 & 0.1244 & 0.1810 & 0.0786 & -0.0639 \\
\hline Food Production Growth & $-0.0397^{*}$ & -0.0264 & -0.0344 & -0.0221 & $-0.0491 *$ & -0.0273 \\
\hline$(\mathrm{t}-1)$ & -0.0376 & -0.0067 & -0.0523 & -0.0084 & $-0.0461 *$ & 0.0074 \\
\hline Real Interest Rate & $-0.2100 * * *$ & -0.0967 & $-0.1660 * *$ & -0.1131 & $-0.1997 * * *$ & -0.1402 \\
\hline$(\mathrm{t}-1)$ & $-0.2335^{* * *}$ & $-0.3950 * *$ & $-0.3105 * * *$ & $-0.3714 * * *$ & $-0.2324 * * *$ & $-0.3706^{* *}$ \\
\hline Broad Money Growth & 0.0276 & 0.0183 & 0.0297 & 0.0230 & 0.0226 & 0.0205 \\
\hline$(\mathrm{t}-1)$ & $0.0885^{* * *}$ & $0.0640^{* *}$ & $0.0752 * *$ & $0.0613 * *$ & $0.0837 * * *$ & $0.0717 * *$ \\
\hline Exchange Rate Growth & 0.0369 & 0.0480 & 0.0366 & 0.1023 & 0.0411 & 0.0531 \\
\hline$(\mathrm{t}-1)$ & $-0.0298^{*}$ & $-0.0371 * *$ & $-0.0300 *$ & $-0.0366^{* *}$ & -0.0263 & $-0.0422 * *$ \\
\hline Openness & $0.0620 *$ & 0.1495 & 0.0761 & 0.1091 & $0.0631 *$ & 0.1376 \\
\hline Voice and Accountability & & 4.2705 & & 2.9444 & & 3.5392 \\
\hline Political Stability & & -3.3779 & & -2.3056 & & -2.6815 \\
\hline Government Effectiveness & & 7.7848 & & 7.0525 & & 7.8491 \\
\hline Regulatory Quality & & 3.8305 & & 1.5148 & & 3.4399 \\
\hline Rule of Law & & 4.9303 & & 4.6838 & & 3.9923 \\
\hline Corruption Control & & $-16.3239 * *$ & & $-13.0004 * *$ & & $-15.4009 * *$ \\
\hline Constant & $13.5728 * *$ & $30.3877 * *$ & $16.9776^{* * * *}$ & $23.4430 * *$ & $13.8921 * *$ & $29.6313 * *$ \\
\hline$\overline{\mathbf{N}}$ & 465 & 325 & 380 & 319 & 465 & 325 \\
\hline Groups & 45 & 43 & 43 & 43 & 45 & 43 \\
\hline $\mathbf{R}^{2}$ & 0.23 & 0.12 & 0.30 & 0.19 & 0.22 & 0.13 \\
\hline \multicolumn{7}{|l|}{$\overline{\mathrm{F} \text { (First Stage) }}$} \\
\hline \multicolumn{7}{|l|}{ F (First Stage) } \\
\hline Dep. Var.: GDP Growth & & & & & $50.4^{* * * *}$ & $76.03 * * *$ \\
\hline \multicolumn{7}{|l|}{ F (First Stage) } \\
\hline Dep. Var.: GDP Growth (t-1) & & & & & $39.22 * * *$ & $37.29 * * *$ \\
\hline Instrumented & Transparency & Transparency & Transparency & Transparency & $\begin{array}{l}\text { Transparency, } \\
\text { GDP Growth, } \\
\text { GDP Growth (t-1) }\end{array}$ & $\begin{array}{c}\text { Transparency, } \\
\text { GDP Growth, } \\
\text { GDP Growth (t-1) }\end{array}$ \\
\hline Instruments & Bank Assets & Bank Assets & $\begin{array}{c}\text { Bank Assets, } \\
\text { Freedom of the Press }\end{array}$ & $\begin{array}{c}\text { Bank Assets, } \\
\text { Freedom of the Press }\end{array}$ & $\begin{array}{c}\text { Bank Assets, } \\
\text { Energy Growth, } \\
\text { Energy Growth (t-1) }\end{array}$ & $\begin{array}{c}\text { Bank Assets, } \\
\text { Energy Growth, } \\
\text { Energy Growth }(\mathrm{t}-1)\end{array}$ \\
\hline
\end{tabular}

Notes: The table shows the results of two stages least squares fixed effects estimations with robust standard errors where the dependent variable is CPI inflation. The asterisks indicate whether a coefficient is significantly different from zero at the $10 \%$ (one asterisk), $5 \%$ (two asterisks) or $1 \%$ (three asterisks) significance level. 
Table 3: Dynamic Panel Data Estimations

\begin{tabular}{|c|c|c|c|c|}
\hline Variable & DPD1 & DPD2 & DPD3 & DPD4 \\
\hline Inflation (t-1) & $0.22793486^{* *}$ & 0.05006107 & 0.04913456 & 0.06310849 \\
\hline Transparency & $-1.5778388 * *$ & $-1.5904954 *$ & $-1.5770906^{* *}$ & $-1.2871377 *$ \\
\hline Central Bank Independence & & 12.726234 & 2.4162663 & 2.8982744 \\
\hline Food Production Growth & 0.27151289 & 0.80487617 & 0.65579326 & 0.69381271 \\
\hline GDP Growth & -0.87253184 & -1.194735 & -2.3605182 & -1.3515154 \\
\hline Real Interest Rate & $-0.18254921 * *$ & $-0.24020982 *$ & -0.08733134 & -0.15858247 \\
\hline Broad Money Growth & $0.16498701 * *$ & $0.17629673^{*}$ & 0.25226697 & $0.2173773 *$ \\
\hline Exchange Rate (LCU per USD) Growth & $0.41678294 * *$ & $0.29012326 * *$ & 0.23475109 & $0.26906531 * *$ \\
\hline Openness & -0.00248556 & -0.01137877 & -0.02102951 & -0.01187721 \\
\hline Polity Fragmentation & 1.6051977 & & & \\
\hline Government Surplus / Deficit & -0.09156031 & $1.0712029 *$ & $1.8292375^{* * * *}$ & $1.0888572 *$ \\
\hline Constant & 4.5409175 & 8.2097012 & $16.833399 * *$ & 10.463265 \\
\hline $\mathbf{N}$ & 492 & 588 & 588 & 588 \\
\hline Groups & 76 & 68 & 68 & 68 \\
\hline Hansen test of Overidentification Restrictions & 33.390456 & 42.408207 & 45.810698 & 42.770181 \\
\hline Arellano-Bond Test for AR(1) in First Differences & $-2.4687505^{* *}$ & -1.2433013 & -1.2111268 & -1.1982971 \\
\hline Arellano-Bond Test for AR(2) in First Differences & -0.62019044 & 0.42696755 & 0.22294369 & 0.25234018 \\
\hline
\end{tabular}

Notes: The table shows the results of system GMM estimations with robust standard errors where the dependent variable is CPI inflation. Lagged inflation, transparency, and GDP growth are treated as endogenous variables. The instruments being used are the lagged endogenous variables plus the lagged nominal interest rate and the lagged population growth. The asterisks indicate whether a coefficient is significantly different from zero at the $10 \%$ (one asterisk), $5 \%$ (two asterisks) or $1 \%$ (three asterisks) significance level. 
Table 4: Determinants of Inflation Volatility

\begin{tabular}{|c|c|c|c|c|c|c|c|c|}
\hline Variable & FE1 & FE2 & FE3 & FE4 & FE5 & FE6 & FE7 & FE8 \\
\hline Inflation & 5.8536 & -7.7623 & $58.8706^{* * *}$ & $40.4878 *$ & $50.3128 * * *$ & * $49.3099 * * *$ & $44.0524 * *$ & -3.3888 \\
\hline$(\mathrm{t}-1)$ & $34.9456 * * *$ & * $35.5933 * * *$ & $32.9165^{* * *}$ & $* \quad 32.5451 * * *$ & $28.1241 * * *$ & $* \quad 27.9684 * * *$ & * $29.5228 * * *$ & $31.1305^{* * * *}$ \\
\hline Transparency & 44.5262 & 27.5803 & -49.0243 & -120.6221 & $-175.2427 *$ & $-169.4863^{*}$ & -140.3082 & 44.4817 \\
\hline Transparency ${ }^{2}$ & 1.9071 & -0.3319 & 4.8075 & $9.8225^{*}$ & $11.2490 * *$ & $10.8887 * *$ & $11.2498 * *$ & -1.6520 \\
\hline$\left(\mathrm{p}_{\mathrm{it}}-\overline{\mathrm{p}}_{\mathrm{i}}\right)\left(\mathrm{CBT}_{\mathrm{it}}-\overline{\mathrm{CBT}_{\mathrm{i}}}\right)$ & -4.4418 & $-6.5884^{*}$ & $-17.9138 * * *$ & $*-15.2548 * *$ & $-20.0986^{* * * *}$ & $*-20.2277 * * *$ & $-24.2177 * * *$ & $-7.1010 * * *$ \\
\hline$\left(\mathrm{p}_{\mathrm{it}}-\overline{\mathrm{p}}_{\mathrm{i}}\right)\left(\mathrm{CBT}_{\mathrm{it}}^{2}-\overline{\mathrm{CBT}_{\mathrm{i}}^{2}}\right)$ & 0.4750 & $0.6499 *$ & $1.4064 * * *$ & $1.3365 * * *$ & $1.7714 * * *$ & $1.7876^{* * *}$ & $2.1252 * * *$ & $0.6491 * * *$ \\
\hline Central Bank Independence & -393.3992 & -420.8839 & -892.8058 & $-922.2668 *$ & 301.9861 & 262.9151 & -337.6066 & -349.8044 \\
\hline Explicit Inflation Targeting & $434.5004 * *$ & 79.9599 & $351.4421 * *$ & $387.9989 * *$ & $337.8750 * *$ & $346.9724 * *$ & $277.6252 *$ & 125.8219 \\
\hline S.D. Exchange Rate Growth & & $1.4001 *$ & $-1.0949 * * *$ & $* \quad-1.1311 * * *$ & $-1.8797 * * *$ & $*-1.8524 * * *$ & $-1.6288 * * *$ & $-0.3555^{* *}$ \\
\hline S.D. GDP Growth & & 12.9984 & 16.2808 & & & & & \\
\hline S.D. M1 Growth & & 3.1290 & & & & & & \\
\hline S.D. M2 Growth & & 1.8596 & 16.1826 & 18.6055 & $51.8526 * *$ & $52.7360 * *$ & $42.4866^{*}$ & $33.1097 *$ \\
\hline S.D. M3 Growth & & -5.1900 & & & & & & \\
\hline Real Interest Rate & & -1.6306 & 1.8650 & 0.2130 & 1.7305 & 1.4251 & 1.5634 & 1.8137 \\
\hline Openness & & -0.8033 & -1.8841 & $-4.1253^{*}$ & -2.0243 & -1.8625 & -1.6668 & -1.7724 \\
\hline GDP Growth & & & & 6.7597 & 11.5199 & 11.0957 & $11.3399 *$ & -7.9382 \\
\hline GDP per Capita & & & & -0.0001 & $-0.0061^{*}$ & $-0.0057 *$ & -0.0030 & $-0.0055^{*}$ \\
\hline Institutionalized Democracy & & & & & 25.8019 & & & \\
\hline Institutionalized Autocracy & & & & & 119.1973 & & & \\
\hline Combined Polity Score & & & & & & -32.9085 & & \\
\hline Civil Liberties and Political Right & & & & & & & $-161.4281 * *$ & \\
\hline Corruption Control & & & & & & & & 183.0432 \\
\hline Government Effectiveness & & & & & & & & -32.4277 \\
\hline Political Stability & & & & & & & & 32.6624 \\
\hline Regulatory Quality & & & & & & & & -69.8914 \\
\hline Rule of Law & & & & & & & & 18.7722 \\
\hline Voice and Accountability & & & & & & & & $-276.3047 * *$ \\
\hline \multicolumn{9}{|l|}{ Transparency $*$ High Inflation } \\
\hline \multicolumn{9}{|l|}{ Transparency ${ }^{2} *$ High Inflation } \\
\hline \multicolumn{9}{|l|}{$\left(\mathrm{p}_{\mathrm{it}-1}-\overline{\mathrm{p}}_{\mathrm{i}}\right)\left(\mathrm{CBT}_{\mathrm{it}}-\overline{\mathrm{CBT}}_{\mathrm{i}}\right)$} \\
\hline \multicolumn{9}{|l|}{$\left(\mathrm{p}_{\mathrm{it}-1}-\overline{\mathrm{p}}_{\mathrm{i}}\right)\left(\mathrm{CBT}_{\mathrm{it}}^{2}-\overline{\mathrm{CBT}_{\mathrm{i}}^{2}}\right)$} \\
\hline \multicolumn{9}{|l|}{ Political Terror (USSD) } \\
\hline Constant & -395.5631 & -165.6347 & -226.8969 & 364.5174 & -617.1969 & -164.2344 & 319.7350 & -103.1557 \\
\hline $\mathbf{N}$ & 640 & 138 & 244 & 373 & 271 & 271 & 301 & 257 \\
\hline Groups & 54 & 13 & 25 & 38 & 32 & 32 & 37 & 37 \\
\hline Adj. $\mathbf{R}^{2}$ & 0.953 & 0.999 & 0.986 & 0.977 & 0.985 & 0.985 & 0.983 & 0.994 \\
\hline Mean VIF & 6.26 & 44.43 & 12.01 & 12.43 & 19.48 & 17.84 & 15.03 & 26.44 \\
\hline
\end{tabular}

Notes: The table shows the results of fixed effects estimations with robust standard errors where the dependent variable is the annual mean of estimated conditional standard deviation based on an $\mathrm{NGARCH}(1,1)$ model. The asterisks indicate whether a coefficient is significantly different from zero at the $10 \%$ (one asterisk), $5 \%$ (two asterisks) or $1 \%$ (three asterisks) significance level. 
Table 4: Determinants of Inflation Volatility (continued)

\begin{tabular}{|c|c|c|c|c|c|c|c|c|}
\hline Variable & FE9 & FE10 & FE11 & FE12 & FE13 & FE14 & FE15 & FE16 \\
\hline Inflation & $46.6950^{* * *}$ & & 27.2298 & $34.7661 * *$ & $46.3874 * *$ & $38.6778^{*}$ & $50.3128^{* * * *}$ & * $45.7347 * *$ \\
\hline$(\mathrm{t}-1)$ & $27.9658 * * *$ & & & & $31.9685^{* * * *}$ & $=31.8663^{* * *}$ & *28.1241*** & $* 29.4880 * * *$ \\
\hline Transparency & $-175.8251^{*}$ & $-358.7000 * *$ & $-341.0415 * *$ & $-334.0620 * *$ & -21.0845 & -35.7060 & $-175.24 *$ & -129.7264 \\
\hline Transparency ${ }^{2}$ & $11.5218^{* *}$ & $15.2457 *$ & 14.2179 & $14.1806^{*}$ & 1.2186 & 3.5966 & $11.249 * *$ & $10.2222 * *$ \\
\hline$\left(\mathrm{p}_{\mathrm{it}}-\overline{\mathrm{p}}_{\mathrm{i}}\right)\left(\mathrm{CBT}_{\mathrm{it}}-\overline{\mathrm{CBT}_{\mathrm{i}}}\right)$ & $-22.1586^{* * * *}$ & & & & & & $-20.099 * * *$ & $*-21.8638 * * *$ \\
\hline$\left(\mathrm{p}_{\mathrm{it}}-\overline{\mathrm{p}}_{\mathrm{i}}\right)\left(\mathrm{CBT}_{\mathrm{it}}^{2}-\overline{\mathrm{CBT}_{\mathrm{i}}^{2}}\right)$ & $1.9330 * * *$ & & & & & & $1.77138^{* * *}$ & $1.9335 * * *$ \\
\hline Central Bank Independence & 335.3516 & -658.3707 & -948.1632 & -723.5971 & -699.4061 & $-975.4240 *$ & 301.986 & -426.5534 \\
\hline Explicit Inflation Targeting & $293.7276^{*}$ & 206.7382 & 258.1649 & 180.7256 & 113.0096 & $341.7421 * *$ & $337.875^{* *}$ & $322.7730 *$ \\
\hline $\begin{array}{l}\text { S.D. Exchange Rate Growth } \\
\text { S.D. GDP Growth } \\
\text { S.D. M1 Growth }\end{array}$ & $-1.7590 * * *$ & * -1.8350 *** & $-1.8759 * * *$ & $-1.9397 * * *$ & $-0.8840 * * *$ & $-1.0185^{* * *}$ & $*-1.8797 * * *$ & $* \quad-1.7885^{* * *}$ \\
\hline $\begin{array}{l}\text { S.D. M2 Growth } \\
\text { S.D. M3 Growth }\end{array}$ & $53.8000^{* *}$ & $232.6163 * * *$ & $231.0116^{* * *}$ & $232.5212 * * *$ & 24.3547 & 22.8485 & $51.8526^{* *}$ & $41.6034 *$ \\
\hline Real Interest Rate & 1.3722 & -9.0965 & -2.2007 & -2.6916 & -2.1090 & 0.2510 & 1.73047 & 1.1133 \\
\hline Openness & -1.9121 & -1.4662 & -4.1683 & -4.8775 & $-5.0450 * *$ & $-4.6521 *$ & -2.0243 & -1.9807 \\
\hline GDP Growth & 12.4906 & 20.4668 & 22.9624 & 19.4006 & 2.8616 & 6.5279 & 11.5199 & 9.0297 \\
\hline GDP per Capita & -0.0049 & -0.0046 & -0.0039 & -0.0057 & 0.0017 & 0.0009 & $-0.0061^{*}$ & -0.0044 \\
\hline Institutionalized Democracy & & & & & & & 25.8019 & \\
\hline Institutionalized Autocracy & & & & & & & 119.197 & \\
\hline Combined Polity Score & $-60.0341^{* *}$ & & & & & & & \\
\hline Civil Liberties and Political Rig & s-194.3854*** & & & & & & & \\
\hline Corruption Control & & & & & & & & \\
\hline Government Effectiveness & & & & & & & & \\
\hline Political Stability & & & & & & & & \\
\hline Regulatory Quality & & & & & & & & \\
\hline Rule of Law & & & & & & & & \\
\hline Voice and Accountability & & & & & & & & \\
\hline Transparency $*$ High Inflation & & & & 16.6247 & $-144.5733 * *$ & & & \\
\hline Transparency ${ }^{2} *$ High Inflation & & & & -14.9163 & $11.1692^{*}$ & & & \\
\hline$\left(\mathrm{p}_{\mathrm{it}-1}-\overline{\mathrm{p}}_{\mathrm{i}}\right)\left(\mathrm{CBT}_{\mathrm{it}}-\overline{\mathrm{CBT}}{ }_{\mathrm{i}}\right)$ & & & & & & -4.6354 & & \\
\hline$\left(\mathrm{p}_{\mathrm{it}-1}-\overline{\mathrm{p}_{\mathrm{i}}}\right)\left(\mathrm{CBT}_{\mathrm{it}}^{2}-\overline{\mathrm{CBT}_{\mathrm{i}}^{2}}\right)$ & & & & & & $0.4510^{*}$ & & \\
\hline Political Terror (USSD) & & & & & & & & -68.7025 \\
\hline Constant & 573.3468 & 955.5450 & 915.8356 & 829.2886 & 118.9959 & 185.9430 & -617.2 & 82.1859 \\
\hline$\overline{\mathbf{N}}$ & 270 & 375 & 375 & 375 & 373 & 373 & 271 & 298 \\
\hline Groups & 32 & 39 & 39 & 39 & 38 & 38 & 32 & 37 \\
\hline Adj. $\mathbf{R}^{2}$ & 0.986 & 0.884 & 0.889 & 0.893 & 0.978 & 0.975 & 0.98495 & 0.983 \\
\hline Mean VIF & 18.97 & 8.2 & 8.22 & 8.47 & 9.03 & 13.03 & 19.48 & 13.94 \\
\hline
\end{tabular}

Notes: The table shows the results of fixed effects estimations with robust standard errors where the dependent variable is the annual mean of estimated conditional standard deviation based on an $\operatorname{NGARCH}(1,1)$ model. The asterisks indicate whether a coefficient is significantly different from zero at the $10 \%$ (one asterisk), $5 \%$ (two asterisks) or $1 \%$ (three asterisks) significance level. 